\title{
Moderate Inclusivism and the Conversational Translation Proviso: Revising Habermas' Ethics of Citizenship
}

\begin{abstract}
:
Habermas' 'ethics of citizenship' raises a number of relevant concerns about the dangers of a secularistic exclusion of religious contributions to public deliberation, on the one hand, and the dangers of religious conflict and sectarianism in politics, on the other. Agreeing largely with these concerns, the paper identities four problems with Habermas' approach and attempts to overcome them: (a) the full exclusion of religious reasons from parliamentary debate; (b) the full inclusion of religious reasons in the informal public sphere; (c) the philosophical distinction between secular and religious reasons; and (d) the sociological distinction between 'Western' and 'non-Western' religions. The result is a revised version of the ethics of citizenship, which I call moderate inclusivism. Most notably, moderate inclusivism implies a replacement of Habermas' 'institutional translation proviso' with a more flexible 'conversational translation proviso'.
\end{abstract}

Key Words: Habermas, The Ethics of Citizenship, Religion in the Public Sphere, Moderate Inclusivism, The Conversational Translation proviso.

\section{Habermas' ethics of citizenship ${ }^{1}$}

There is a tension in deliberative democratic theory between two ideals: the ideal of inclusion and the ideal of generality. According to the ideal of inclusion, the legitimacy of laws, policies and basic rights depends on the extent to which all affected parties are able to raise their concerns and voice their opinions in ongoing processes of democratic deliberation. The ideal of generality, on the other hand, implies a claim about the type of reasons that are appropriate in political deliberation, namely those that can be shared and meaningfully evaluated across sectarian and subcultural divides. The simultaneous commitment to both ideals creates a tension between the right to deliberate according to one's "authentic cognitive stance" (Lafont 2013, 231-232), on the one hand, and the duty to present others with reasons that they can understand and asses in virtue of their "common human reason" (Rawls 2005, 137), on the other. Put differently, there might be cases in which citizens have to choose

\footnotetext{
${ }^{1}$ I thank anonymous reviewers and members of the research group Pluralism, Democracy and Justice (UiT The Arctic University of Norway) for comments and suggestions.
} 
between (a) disclosing "the whole truth as they see it" (Rawls 2005, 216) in a political dispute, and (b) saying something that others can recognize as a valid or at least legitimate political argument.

Even though the tension between inclusion and generality applies to political debates in general, it is the specific case of religious argumentation that has received the most attention in political philosophy. ${ }^{2}$ This is due not just to the fact that religion in politics is a theme that engages many citizens as well as philosophers, it also has to do with the fact that religious reasons are considered by many to be paradigmatically sectarian or non-shareable (Lafont 2013, 232). As Boettcher puts it: "Religious traditions have different authoritative texts, social teachings and methods of interpretation, and citizens cannot be expected generally to share distinctively religious standards of evaluation for political claims" (Boettcher 2009, 221-222). Along similar lines, Habermas argues that religious claims to validity "remain particularistic even in the case of proselytizing creeds that aspire to worldwide inclusion" $(2013,374)$.

For Habermas, the truly distinguishing feature of religion - its "Alleinstellungsmerkmal" $(2012,104)$ - is its rootedness in cultic practices, and the corresponding distinction between members and non-members: "By using any kind of religious reasons, you are implicitly appealing to membership in a corresponding religious community" $(2011,61) .^{3}$ Religious reasons therefore fail to satisfy the criterion of generality, and there is always a risk that leaders and charismatic figures will exploit the strong potential for group-based solidarity in religious traditions for sectarian or even violent purposes (2008a). If religious reasons are unleashed without modification in institutionalized politics, the political community is "in constant danger of disintegrating into religious conflicts" (2008, 135). Given that the validity of religious reasons depends on the acceptance of "the dogmatic authority of an inviolable core of infallible revelatory truths" $(2008,129)$, these conflicts cannot be resolved "at the cognitive level" $(2008,135)$, that is, through communicative means, but only through non-communicative means, such as voting, majority rule, bargaining, political power, or even violence.

\footnotetext{
${ }^{2}$ See for example Audi 1997; Wolterstorf 1997a; Eberle 2002; Taylor 2011; Waldron 2012; March 2013; Laborde 2017.

${ }^{3}$ Lasse Thomassen mistakenly believes that, "for Habermas, religion provides a privileged example of ethical worldviews" $(2006,450)$. In fact, Habermas argues that ethical reasons are secular and therefor open to rational examination in a way that religious reasons - given their reliance on revealed doctrines of faith - are not: "Religiously rooted existential convictions (...) evade the kind of unreserved discursive examination to which other ethical orientations and worldviews, i.e. secular 'conceptions of the good' are exposed" (Habermas 2008, 129).
} 
According to Habermas, however, simply excluding religious reasons from political deliberation due to their lack of generality would create two serious problems in the political culture, one related to injustice and the other related to the functional requirements of modern democracies.

The first problem with excluding religious argumentation (the problem of injustice) is that an unfair asymmetry is created in the political culture, given that religious citizens will face an "unreasonable mental and psychological burden" that other citizens do not face (2008, 130). If secular political discourse becomes the norm that everyone must obey, then, Habermas believes, nonreligious citizens are able to speak their minds freely and directly whereas religious citizens are forced either to find a secular 'translation' of the view they wish to advocate, or withdraw from the debate. This is not necessarily a problem for all believers, but it will be a significant burden for those "monolingual" citizens $(2008,130)$ who are unable to distinguish between politics and religion. For them, the requirement of generality in political discussions will be experienced as "an attack on their personal identity" $(2008,130)$. From the standpoint of justice, this is a problem because the conditions for political participation - for realizing one's political autonomy - are unequal. ${ }^{4}$

The other problem with excluding religious argumentation from public deliberation has to do with the functional requirements of a liberal democracy. A stable and wellfunctioning democracy depends crucially on the active participation of the citizens (Habermas 2003a, 27) as well as on the citizens' attitudes and political virtues, such as the willingness to listen to opponents, to include minorities and marginalized groups in the political culture, and to sometimes sacrifice private goals for the sake of the common good (Habermas 2008, 105). Now, according to Habermas, religious traditions have the potential not only to motivate and inspire their own followers to take active part in politics and civil society, but also to contribute with insights, perspectives and motivational resources to the political culture more broadly (Chambers 2007). For example, religious vocabularies have the potential to counterbalance the pressures from unbound capitalism and bureaucratization, as well from naturalistic worldviews and understandings of the human person, as manifested for example in genetic manipulation, which, according to Habermas, threaten to reify human relations and self-relations (2003b). By this, they keep alive a sensitivity for something that money, power

\footnotetext{
${ }^{4}$ I provide a critical discussion of this argument - Habermas' 'split identity objection' to Rawls and the standard liberal position - in part 3 of this paper.
} 
and science cannot produce, namely a lifeworld that provides citizens with resources of meaning, identity and solidarity in a still more fragmented modernity:

The liberal state has an interest in unleashing religious voices in the political public sphere, and in the political participation of religious organizations as well. It must not discourage religious persons and communities from also expressing themselves politically as such, for it cannot know whether secular society would not otherwise cut itself off from key resources for the creation of meaning and identity $(2008,131)$.

By this, we should be able to see why Habermas" "ethics of citizenship" $(2008,140)$ attempts to overcome the tension between inclusion and generality, that is, to articulate the normative expectations associated with democratic citizenship in a way that takes both ideals into account. One the one hand, religious argumentation fails to satisfy the criterion of generality, and therefore poses a potential threat to the "unifying bond" $(2008,105)$ of multicultural democracies. On the other hand, completely excluding such arguments from political deliberation would not only be unfair, it would also cut modern societies off from important moral and ethical-political resources (the first pertaining to universally binding norms, the second to more context-bound democratic values, meanings and identities). So, how does Habermas' ethics of citizenship conceptualize the required balance between generality and (religious) inclusion?

Habermas' proposal is to articulate a dualistic conception according to which generality is taken care of in the formal or institutional public sphere, most basically in parliaments, courts, ministries and administrations (Habermas 2008, 130), while inclusion is taken care of in the informal or "wild" (Habermas 1998, 307) flows of communication that run through different non-governmental publics and are channeled by mass media (Habermas 2006). With regard to the first, formal, sphere, Habermas sides with Rawls and the liberal tradition (e.g. Audi 1997; Boettcher 2009) against religious inclusivists such as Cooke (2007), Eberle (2002), and Wolterstorf (1997): "all coercively enforceable political decisions must be formulated and justifiable in a language that is equally intelligible to all citizens" (Habermas 2008, 134). For Habermas, this 'must' implies not just a normative claim imperative but also an institutionally and legally enforceable exclusion of religious arguments: "In parliament, the rules of procedure must empower the house leader to strike religious positions or justifications from the official transcript" $(2008,131)$. This, of course, does not mean that religious citizens cannot advocate religiously inspired views and policies, based on religious values, but it means that these views should be translated into generally accessible and 
rationally examinable claims before entering the institutional threshold of the formal public sphere - also known as Habermas" "institutional translation proviso" $(2008,130)$.

With regard to the second, informal sphere, Habermas believes that this is the place to fully include religious citizens and their contributions to public life in general and political deliberation in particular. The informal sphere (or spheres) includes the media, civil society and other forums of public debate outside of the state. It forms a "context of discovery" $(1998,307)$ in which the citizens' experiences, aspirations, hopes, identities, opinions, etc., are articulated, debated and revised in ongoing processes of communication and critical reflection. By taking part as free and equal deliberators in these processes, religious citizens are to influence the democratic process 'from below', freely prioritizing what they see as the better argument, while at the same time accepting an institutional translation proviso 'from above'.

For Habermas, however, merely tolerating religious arguments in the informal sphere is not enough. In order to truly include religious citizens on equal, symmetrical conditions, non-religious citizens must be willing to listen to, and learn from, their religious co-citizens: They must remain cognitively open to the rational insights of religious speech. Remember that, according to Habermas, religious citizens bear an asymmetrical burden in the public sphere: the institutional translation proviso is only a burden for them, not for secular citizens. The only way to mitigate this burden, he believes, is for religious citizens to participate in a joint translation process with their religious co-citizens. In this process, they should look actively for truth contents in religious argumentation and attempt to encapsulate these from particular religious doctrines so that they can be included as reasons in the formal sphere: "a liberal political culture can even expect its secularized citizens to participate in efforts to translate relevant contributions from the religious language into a publicly accessible language" (Habermas 2008, 310).

Christine Lafont, however, argues that this expectation makes excessive demands on non-believers in public deliberation, expecting them to conceal their true opinions about religion, say, their authentic views on the religious opposition to homosexual marriage:

Let's take the example of the current political debate on gay marriage. It is hard to see why a serious engagement in this debate would require secular citizens to open their minds to the possible truth of religious claims against homosexuality. It seems to me that a perfectly serious way of engaging in that debate is to offer the objections and counter arguments needed to show why the proposed policy is wrong, if one thinks it is. Objecting to the unequal treatment involved in denying the right to marriage to a group of citizens, or appealing to anti- 
discrimination laws to justify opposition to this policy seem perfectly appropriate ways to participate in such public debate (Lafont 2013, 239).

I agree with Lafont that it would be utterly unjustified to expect secular citizens to remain 'cognitively open' to particular interpretations of what the Bible or the Quran say about homosexuality, at least if 'open' means that one is expected to look actively for their 'truth content'. It is therefore important to point out that the cognitive openness that is required of non-believers does not imply any duty to take an affirmative or uncritical stance to religious speech as such. The point is rather that there may be valuable potentials in religious speech, and that the view that religion has nothing to offer an enlightened humanity - "enlightenment fundamentalism" (Habermas 2008a) - is therefore false. In a response to Lafont, Habermas therefore stresses that the ethics of citizenship does not repress secular citizens' disbelief in religion, but simply encourages them not to dismiss public speech merely because it is religious:

Secular citizens can meet this obligation [the ethics of citizenship] without denying their own disbelief in any kind of religious teaching. They are only asked not to exclude the possibility that religious speech might contain traces of a lost or repressed, or otherwise unavailable, normative intuition that is compelling and still awaits a saving translation (Habermas 2013, $372)$.

In my view, Lafont's critique is nevertheless important because it points to a weakness in Habermas' understanding of contemporary religion. There is a tendency in Habermas to regard religion as either 'good' or 'bad': Religion is either characterized as an intolerant fundamentalism or as an inspirational source of meaning, identity and morality. This is probably a meaningful way of describing some religious groups and traditions, but certainly not all. For example, conservative religious views on the nuclear family, abortion, or homosexuality, may neither be fundamentalist nor contain the kind of epistemic insights that Habermas wants secular citizens to look for. The normative requirement of openness can therefore be maintained only in a very abstract sense, as in 'do not dismiss all religious speech simply in virtue of being religious'. It cannot be maintained as a requirement to reflect deeply on the possible truth content of every argument that religious citizens put forward in public discourse, and it certainly cannot imply any duty to refrain from disagreement with religious speech qua religious. As McCarthy puts it: "channeling religious views on to an ethical track [by translating them into secular conceptions of the good] does not end disagreement: it opens the field to reasonable disagreements about ethical matters" (McCarthy 2013, 128). 


\section{Moderate inclusivism and parliamentary debate}

This paper sympathizes with Habermas' attempt to integrate the ideals of inclusion and generality in the philosophical debate about religious reasons in the public sphere.

Nevertheless, the following sections argue in favor of specific revisions of his approach, beginning with the full exclusivism he defends in the domain of parliamentary debate, and advocating instead what I call a moderate inclusivism.

I agree with Habermas that religious reasons (as he understands them) have no place in the law, the constitution or the courtroom. However, parliamentary debate is different because it provides a forum for political contestation and deliberation before policies and legislation are given their final form and enacted by the majority. As Rostbøll argues, there is a principal difference between the reasons we initially bring to a process of political deliberation, and the justifications we settle on when we make decisions $(2008,118)$. To be sure, this is a very Habermasian point, but the difference is that, within certain limits, I believe that controversial, provocative, and non-shareable reasons should be tolerated also in parliamentary debate and not just in the weak or informal public spheres (Habermas 1998, $304-314)^{5}$

To see why, consider Rawls' point that imposing the duty of civility as a legal constraint would be incompatible "incompatible with free speech" $(2005,445)$. This is important because the legitimacy of laws and constitutional principles hinges on the fairness and formal features of the preceding processes of argumentation and counter-argumentation. If these procedures are in any way asymmetrical or biased, the outcome cannot be justified to all parties (say, the loosing numerical minority) with reference to the fairness of the democratic process itself. Given that there are many types of non-religious speech that are just as controversial, and just as unintelligible to outsiders, as is religious speech (Taylor 2011), formally restricting the free speech of religious members of parliament, and only these, is bound to produce distrust in the democratic procedure. If, say, atheists or representatives of non-religious cultural groups are free to articulate their "comprehensive doctrines" (Rawls 2005, 58) in parliamentary debates, why not, say, Christians or Muslims? Why should populist anti-immigration rhetoric be tolerated, but not religiously justified defenses of our duty to alleviate suffering and poverty, or combat climate change? Habermas could of course reply that all political justifications that are based on controversial worldviews should be

\footnotetext{
${ }^{5}$ My aim in this paper is not to take a position on these limits, but I would certainly not include racist epithets or incitements to violence in the domain tolerable speech.
} 
expelled from parliamentary discourse, but this would lead him down a dangerous road of paternalism and state interference with free speech.

On this background, I reject Habermas' full exclusivism in parliamentary debate. However, my rejection does not entail a full-blown inclusivism in the style or Wolterstorf (1997), Eberle (2002) or Cooke (2007), but rather what I call a moderate inclusivism. ${ }^{6}$

Moderate inclusivism agrees with Habermas that there are normative expectations and duties of civility in parliamentary deliberation, but, in line with Rawls, it conceives these obligations as ethical, not legal or institutional. ${ }^{7}$ As Rawls puts it in his famous 'proviso', we should be allowed to "introduce into political discussion at any time our comprehensive doctrine, religious or non-religious, provided that, in due course, we give properly public reasons to support the principles and policies our comprehensive doctrine is said to support" (2005, 453).

The reason why politicians and lawmakers have a duty to supplement comprehensive arguments with 'properly public' ones is related to the mutual respect they - and the groups they represent - owe each other qua free and equal members of the political community. Consider Nussbaums point that "even if governments don't coerce people, the very announcement that a given religion (or antireligion) is the preferred view, is a kind of insult to people who in all conscience cannot share this view and wish to continue to go their own way" $(2012,242-243)$. If this is true, it follows that there is also something disrespectful about arguing that the state should defend a particular faith or controversial worldview. According to moderate inclusivism, therefore, respect for persons qua free and equal should be reflected also in the deliberative process that takes place before majority decisions are made in parliament. Lawmakers, in other words, should (attempt to) state their political positions in terms that all citizens are able to understand and evaluate in virtue of "their common human reason" (Rawls 2005, 137).

Moderate inclusivism, as presented so far, guarantees free speech in a non-arbitrary fashion in parliamentary debate. It also considers religious argumentation as ethically permissible in such debate, as long as it is supplemented 'in due course' with more accessible reasons. However, in order to be fully convincing, this position still needs some further

\footnotetext{
${ }^{6}$ With Kjersti Fjørtoft, I develop the most basic features of moderate inclusivism in Jakobsen and Fjørtoft 2018. The present paper develops the position in new directions and takes up different aspects of Habermas' theory. ${ }^{7}$ In fact, Rawls characterizes the duty of civility as a "moral duty" $(2005,445)$, not as an ethical one. The reason why I use 'ethical' rather than 'moral' has to with Habermas' distinction between the 'moral' and the 'ethicalpolitical': The first referring to universally binding norms, the second to more context-bound norms and expectations associated with liberal democratic citizenship. My argument in favor of moderate inclusivism in this paper is an ethical-political one and leaves the stronger debate about universal validity aside.
} 
clarifications. Consider the case of a Christian member of parliament - politician $\mathrm{X}$ - who appeals to her faith in order to advocate a policy of inclusion and equality, or even neighborly love, in the domain of immigration and asylum policy. Imagine also that neither those who agree, nor those who disagree, with politician $\mathrm{X}$ are bothered by her religious language as such. Those who disagree criticize the policies she suggests, and those who agree but do not share her religious faith simply translate her religious arguments into secular arguments about human rights, dignity, and moral responsibility, perhaps without even thinking about it. If politician $\mathrm{X}$ does not provide a 'proper political argument' in due course, does that mean that she is behaving uncivilized or disrespectfully?

In contrast to both Rawls and Habermas, moderate inclusivism does not hold the strong view that religious argumentation without 'secular supplementation' is always uncivil in parliamentary deliberation, regardless of the particular discursive situation in which it emerges. If no participants in a discussion are worried by a specific religious argument, if no one fails to understand it or feels that it blocks the rationality of the discussion, then there is nothing wrong with it, at least not qua religious. If, however, the receivers of a religious argument are uncomfortable with it, find it disrespectful, or simply fail to understand its precise content and premises, they have a right to ask for a non-religious equivalent or 'translation' of that argument, and the speaker has a duty to (attempt to) provide one. Put differently, lawmakers have a "right to justification" that respects the criteria of "reciprocity" (what X demands for herself must be equally demanded for everyone else) and "generality" (the reasons she uses must be shareable for all) (Forst 2011, 6), but they also have the capacity to decide for themselves precisely when a religious argument violates these criteria. They do not need a political theorist to decide this for them in advance.

On this basis, I suggest to revise Habermas' 'institutional translation proviso' in the following way. First, as already mentioned, the proviso is ethical rather than legal in the domain of parliamentary debate; otherwise it would be incompatible with a non-arbitrary defense of free speech. Second, lawmakers do not have a duty to come up with noncomprehensive reasons unless they are asked to do so by those they deliberate with. Thus, lawmakers may freely refer to their comprehensive religious or non-religious doctrines in parliamentary debate, and there is no general duty to always supplement religious reasons with non-religious ones, but there is a duty to provide a non-comprehensive translation of political standpoints if and only if such a translation is called for by co-discussants. I shall refer to this duty as the 'conversational translation proviso' (CTP), given that it is triggered in conversation, not prescribed as a presupposition for respectful conversation. 
The CTP solves a problem with Rawls" "idea of public reason" $(2005,441)$ and Habermas' ethics of citizenship, namely that, as Chambers notes, it is often difficult to know whether a specific religious argument is justificatory or not:

When is quoting from scripture or appealing to Divine powers a justification and when is it simply a rhetorical flourish? When are religious appeals inspirational and motivational and when are they justificatory? When is God-talk part of a set of interlocking, parallel or convergent reasons and when is it the exclusive foundation of a proposal? We need to know these things to be able assess whether an utterance falls outside of public reason (Chambers $2010,16)$.

Justificatory religious arguments (say, 'this law is wrong because it goes against what the Bible says') are clearly problematic in political debates because they assume that all citizens are bound - not just spiritually and morally but also politically and legally - by the authority of specific doctrines, scriptures, practices or holy figures. However, as Waldron notes (also Rawls 2005, 462 -466), there are many other types of "respectable speech acts" in political deliberation than justificatory ones (Waldron 2012). To take Waldron's example: When a religious spokesperson takes a public stance against torture, she might want to draw attention to an important topic, to address fellow believers, or simply to explain her view to others, without expecting non-believers to be persuaded by the religious premises of her view (Waldron 2012, 858). A rigid and general exclusion of 'religious arguments' is therefore likely to exclude what was never intended to be a justificatory political argument, but merely, say, an explanation or clarification of a viewpoint. Surely, we cannot expect believers to always make it explicit that 'this is what I believe, but I accept that you believe otherwise'.

The CTP solves this problem because it avoids an overly rigid application of Habermas' as well as Rawls' respective provisos. It does not require a translation when no one demands it, and it allows the question of justificatory versus non-justificatory reasons to be settled by discussants themselves: If I am in doubt about the intentions of a religious argument, then I am free to investigate it, asking the speaker to clarify why he or she makes it, and whether it is meant to be justificatory or not.

Finally, given that modern liberal democracies are diverse and multicultural, the likelihood that all members of parliament belong to the same religion (or even identify with a religious tradition) is small, and so is the risk that the CTP is never triggered in practice. However, in order to avoid situations where all lawmakers share the same religious beliefs, justifying the law in religious terms that minorities cannot accept, moderate inclusivism adds a final normative premise, namely that representatives of cultural-religious minorities are 
regularly consulted, allowing them to trigger the CTP and ask for non-religious justifications. I call this the 'duty of consultation'.

\section{The informal public sphere}

Having addressed some of the difficulties with Habermas' exclusion of religious argumentation from parliamentary debate and suggested a revised approach called moderate inclusivism, I now proceed to examine whether moderate inclusivism and its CTP is a convincing alternative also for the informal public sphere. I shall argue that it is.

The first argument in favor of moderate inclusivism in the informal sphere is that it preserves an important ethical intuition about equal respect. In the previous section I briefly mentioned that respect between free and equal citizens implies a duty for lawmakers in parliament to supplement comprehensive arguments with non-comprehensive ones, if asked to do so, at least in political controversies over coercive law, institutional design and policy making. But why should this duty apply only to lawmakers and state officials? If a religious spokesperson insists on national television that a particular law should be enacted in accordance with specific Christian or Islamic doctrines, refusing to give any kind of nonreligious justification, she also suggests that those who do not share her faith are nevertheless bound by it, and that she is willing to impose her faith on all others through politics and law. This is incompatible with the kind of basic respect that Habermas himself sees as the essence of a "liberal political culture", namely "symmetrical relations of reciprocal recognition, including those between the members of different identity groups" $(2008,293)$.

So, whereas Habermas "extends carte blanche to the religious citizen who wishes to advance religious arguments for political positions" (Neal 2014, 324), moderate inclusivism expects all citizens to obey the CTP, at least when engaged in political deliberation about legal coercion and basic rights. By this, moderate inclusivism takes seriously Habermas' own claim that free and equal citizens "owe one another good reasons" $(2008,121)$, and it distributes the "normative expectations associated with democratic citizenship" $(2008,136)$ equally to all citizens, including religious ones. Of course, what exactly counts as being 'engaged in deliberation' is a controversial issue that I do not attempt to solve here. I do, however, think that two conditions should be met, namely publicness and consent. Publicness implies that the place of deliberation is a genuinely public political forum such as radio, television or newspapers. Consent implies that that deliberating parties know and recognize that they are deliberating. On such a narrow definition, of course, there are many types of 
public discourse, and many types of political expressions and statements, that do not count as 'deliberation', meaning that the citizens are not bound by the CTP.

The second argument in favor of moderate inclusivism is a consequentialist one, namely that public deliberation is unlikely to produce the kind of solidarity, mutual understanding and even "constitutional patriotism" $(1998,500)$ that Habermas hopes for, as long as the informal public sphere is permeated by the political use of religious or otherwise sectarian speech. In order to elaborate this point, consider the two main reasons why Habermas believes that the formal public sphere must be secular. First, Habermas argues that "by opening parliaments to conflicts over religious certainties, governmental authority can become the agent of a religious majority that imposes its will in violation of the democratic procedure" $(2008,134)$. In parliamentary debate, therefore, majority rule take a repressive form if a religious majority refuses to offer political justifications that the outvoted minority, "be it secular or of a different faith", can "follow and evaluate in the light of shared standards" (2008, 134). Second, in his criticism of Wolterstorff's inclusivism, Habermas argues that the use of religious argumentation in formalized politics introduces a type of conflict into the political system that cannot be solved deliberatively, "at the cognitive level" (2008, 135). Following Wolterstorff's model, therefore, would lead to a situation in which the political community would always be in danger of disintegrating into religious antagonism and conflict (Habermas 2008, 135).

I believe Habermas' is correct in pointing to these risks - the risk of majoritarian domination and the risk of antagonistic conflict - but I do not see why they are not equally present, and, potentially, equally damaging, in the informal public sphere(s). Why should these risks disappear when citizens address conflicts, disagreements or controversial topics in mainstream media, social media or other channels of political communication? It seems uncontroversial to say that the majority's insistence on religious language in political disputes may function as a kind of discursive dominance or provoke a spiral of antagonistic conflicts, also in the broader channels of public communication. Citizens know that the forms of communication that take place in the informal spheres affect institutionalized politics. The insistence on religious justifications by one group is therefore likely to worry other groups or disrupt ties of solidarity and trust in pre-formal discursive contexts. These risks are not really considered by authors who cite Habermas in order to defend the full and unmodified inclusion of religious reasons in the informal public spheres, such as Cecile Laborde $(2017,125)$, Maeve Cooke (2007) and Simone Chambers (2007). 


\section{The split identity objection}

The previous section considered an ethical and a consequentialist argument for preferring moderate inclusivism over Habermas' full inclusivism in the informal public spheres. The present section revisits Habermas' 'split identity argument' to see whether it creates a problem for moderate inclusivism. After all, the split identity objection is intended to demonstrate the overly demanding and unjust nature of any approach that confronts religious believers with normative expectations in the informal domains of public deliberation.

As mentioned in section 1, the split identity objection pertains to the alleged unfairness of demanding something of religious citizens that is psychologically burdensome for them - and only for them. "To date", Habermas argues, "only citizens committed to religious beliefs are required to split up their identities, as it were, into their public and private elements" (Habermas 2003, 109). Given that this asymmetry characterizes the formal public sphere and its institutions, Habermas argues, one way of compensating the religious is to grant them a full and unmodified right to use religious arguments and justifications in the informal spheres, such as public media and other non-governmental fora of deliberation.

By claiming this, Habermas accepts a variant of the so-called "split identity objection" (Yates 2007, 881) or "integralist objection to political liberalism" (Jensen 2005, 158), as articulated by authors such as Nicholas Wolterstorff and Christopher Eberle. This objection is based on the idea that, unlike non-religious citizens, (some) religious citizens are simply unable to make any kind of distinction between their religious identity and their political viewpoints (Eberle 2002, 145). As Wolterstorf puts it: "Their religion is not, for them, about something other than their social and political existence" (Wolterstorff 1997a, 105).

In fact, however, it is difficult to find a political standpoint that religious citizens or spokespersons want to defend but cannot defend without relying only on specific doctrines of faith. Audi, for example, states that controversial issues such as abortion, homosexuality, affirmative action, or periods reserved for prayer or meditation in schools are "easily approached from the points of view of natural law and secular justice" (Audi 1997, 127). His point is not merely that religiously inspired positions can be stated in a secular vocabulary, but also that secular reasons are not necessarily alien or external to the identity of the religious citizen. As Habermas puts it, "religious certainties of faith are interconnected with fallible convictions of a secular nature" $(2008,129)$, meaning that secular and religious reasons are not antithetical as such, but interwoven within the religious worldview. 
To further illustrate this point, consider the case of abortion. The religious objection to abortion is regarded by some inclusivists as a paradigm example of a viewpoint that cannot be articulated in secular terms. According to Thomassen, for example, "thinking of about abortion according to this distinction between the ethical [or religious] and the political is precisely what the anti-abortionist cannot do. For her, it is not a question of political procedure, but of divine revelation transcending any ethical-political distinction" (Thomassen 2006, 444). Is Thomassen right that the anti-abortionist cannot express her authentic cognitive stance in non-religious terms? According to Waldron, Christian opponents of abortion tend not to base their arguments on 'divine revelation':

The argument against abortion, such as it is, is mainly a natural law argument based on the apparent continuity of fetal development and it is perfectly intelligible to a secular moral sensibility. The religious aspect is just the disciplined insistence on taking the continuity of human life (both in and outside the womb) seriously in light of what biblical faith tells us about the preciousness of human life generally (Waldron 2012, 855).

Something similar can be said about the Islamic position, at least as interpreted by the influential Sunni scholar, Yusuf Al-Qaradawi: "Muslim jurists agree unanimously that after the fetus is completely formed and has been given a soul, aborting it is haram. (...) it constitutes an offence against a complete, live human being (Al-Qaradawi 1994, 201). Qaradawi does not refer to 'divine revelation', but describes an Islamic moral argument about when the human being has a soul - and moral and legal rights as such. ${ }^{8}$ As March notes, it is precisely because non-believers do not need to accept particular revelatory claims or the authority of clerical figures that they can understand much of the religious opposition to abortion, torture and euthanasia, and accept it as morally relevant (March 2013, 529). Arguing that 'life begins at conception' or that 'all human life is sacred' does not count as religious argumentation in Habermas' sense: There is no reference to revealed doctrines, holy prophets or sacred scriptures, and there is no appeal to membership in a specific community of faith.

To conclude this section, it seems exaggerated to say that moderate exclusivism and its CTP, when applied to the informal public spheres, imposes an unbearable psychological burden on the religious, and threatens their personal integrity. Sometimes, in some situations, believers who put forward a religious argument political disputes will be asked to supplement this argument with a less sectarian one, but, for all we know about the complex

\footnotetext{
${ }^{8}$ Please note that I am neither defending nor criticizing standpoints about abortion here, but simply analyzing their alleged 'religious' character.
} 
interrelatedness of religious and secular reasoning, they will hardly be asked to speak a 'foreign' langue that threatens their religious identity.

\section{Secular and religious reasons}

In the previous section, I argued that Habermas' split identity argument overstates the burden of translation that confronts believers who are asked to supplement religious with nonreligious argumentation. Another counterargument against the split identity objection that I find convincing pertains not so much to the alleged psychological pain involved in translating religious into non-religious argumentation, but to the assertion that only believers are burdened by the ethics of citizenship. In short, this argument says that also non-believers, and not only believers, may at times find it difficult to use a 'shareable' political vocabulary in public debates. Also comprehensive secular doctrines, so the argument goes, may be too sectarian to count as 'public-political' in the relevant sense. Obeying the ethics of citizens may sometimes be frustrating, but the burden is not asymmetrically distributed in favor of non-religious citizens, as Habermas believes.

The reason why Habermas believes that secular citizens are not burdened by the normative expectations of democratic citizenship is that, on his account, secular reasons are per definition public and fallible: "secular reasons can be expressed in a 'public' or generally shared language" (Habermas \& Taylor 2011, 61). However, as Christina Lafont points out, non-religious reasons that are based on different and conflicting conceptions of the good cannot be considered generally shareable just in virtue of being secular (Lafont 2013, 232; also Taylor 2011). This is also Craig Calhoun's point when stating that both religious and secular orientations to the world depend on strong epistemic and moral commitments that are partly pre-reflexive and pre-rational: "secular reasons are also embedded in culture and belief and not simply matters of fact or reason alone" (Calhoun 2011, 82). On this background, moderate inclusivism argues with Rawls that the relevant distinction to draw when outlining a normative ethics of citizenship is not between secular and religious, but between shareable and non-shareable. The distinction between shareable and non-shareable may then be drawn and conceived in different ways, but the important point is to avoid the untenable claim that secular reasons are always shareable. In Rawls' words: “we must distinguish public reason from what is sometimes referred to as secular reason and secular values. These are not the 
same as public reason. For I define secular reasoning in terms of comprehensive nonreligious doctrines" (Rawls 2005, 452). ${ }^{9}$

By abandoning the distinction between 'shareable secular' and 'non-shareable religious' reasons, moderate inclusivism also distances itself from Habermas' generalized distinction between secular and religious 'consciousness':

[S]ecular consciousness has no difficulty in recognizing that an alien ethos has the same authenticity and the same priority for the other as one's own ethos has for oneself. The situation is different for the believer who draws her ethical self-understanding from religious truths that claim universal validity. As soon as the idea of the correct life takes its orientation from religious paths to salvation or metaphysical conceptions of the good, a divine perspective (or a 'view from nowhere') comes into play which (or from where) other ways of life appear not just different but mistaken (2008, 309).

It is true that secular political philosophy prioritizes worldview pluralism above the commitment to a 'correct' way living, but not that all secular citizens do. For example, atheists may very well find religious ways of life mistaken in the sense that they are based on false claims about the nature of reality, the existence of God, or man's purpose in the world, and this view may lead them into a political struggle against the public influence of religion. Atheists who still want to comply with the ethics of citizenship may therefore face some of the same difficulties as religious citizens, i.e. they may have to admit that the concern with justice requires them to exercise some self-restraint when justifying their political positions to fellow citizens. Of course, Habermas might agree with this particular point, and he might argue that my reading of passage just cited is too rigid. However, he cannot agree with the normative conclusion I draw without revising his position, namely that as long as both religious and non-religious citizens at times find it difficult to obey the ethics of citizenship, the burden of public deliberation is not asymmetrically distributed.

\section{Western and non-Western religions?}

What I have argued so far is that moderate inclusivism and its CTP is a better and more convincing alternative for the formal and informal public spheres than is Habermas' current formulation of the ethics of citizenship. Also, I have defended moderate inclusivism against Habermas' 'split identity objection', in particular because it relies on an unconvincing claim

\footnotetext{
${ }^{9}$ A further (Rawlsian) reason to avoid premising moderate inclusivism on Habermas' overall theory of communicative rationality and 'secular reason', is that, as Thomas McCarthy argues, this theory amounts to a comprehensive philosophy, and is highly controversial as such (McCarthy 2013, 117). That does not mean that the theory is wrong, merely that reasonable persons will disagree about it, and that moderate inclusivism does not need to subscribe to it as a whole to defend itself.
} 
about the asymmetrical 'burden of translation', as well as on a problematic distinction between secular and religious reasons.

The final section addresses a further issue in Habermas' understanding of religion in the public sphere, namely the distinction between 'Western' and 'non-Western' religion, and the normative implications he draws from this distinction for the ethics of citizenship. Pace Holst and Molander (2015, 553-554), Habermas does not regard all religious people as devout in a "totalizing sense", incapable of distinguishing between secular morality and specific doctrines of faith. According to Habermas, namely, a distinguishing feature of "Western culture" is the historical "transformation of religious consciousness," which has enabled religious members of this culture to come to terms with the normative requirements of the secular state and to relate to their own truth claims in a "self-reflexive manner" $(2008,137)$. After all, therefore we can expect members of 'Western' Judeo-Christian faith communities to observe the normative expectations associated with democratic citizenship. Habermas is no doubt right that large differences exist with regard to the integration of secular-liberal norms into the doctrines and practices of different religious communities. However, drawing the relevant distinction between 'Western' and 'non-Western' leaves the question of Islam and other religions "worryingly unanswered" (Audard 2011, 229).

Some critics interpret Habermas' remarks about the differences between Western and non-Western religions as Eurocentric and Islamophobic (e.g. Mavieli 2012). Jansen, for example, argues that Habermas expresses exactly the kind of downgrading and prejudiced attitude towards Islam and Muslims, which characterizes much islamophobic discourse today (Jansen 2011). Jansen refers mainly to Habermas' essay "Notes on Post-Secular Society" (Habermas 2008a) in which he notes how long it took before Catholicism and Protestantism officially committed themselves to the principles of human rights and democracy: " $[\mathrm{t}] \mathrm{he}$ Catholic Church first pinned its colors to the mast of liberalism and democracy with second Vaticanum in 1965. And in Germany, the Protestant Church did not act differently" (2008a, 27). Having observed this, Habermas then goes on to argue that "many Muslim communities still have this painful learning process before them" (Ibid., 27). In the German version of the same text, the claim is not that 'many Muslim communities' have a learning process before them, but that "Islam" has (2008b).

What I take Habermas to mean is that mainstream Islamic theology has not made itself compatible with modern egalitarianism (human rights and democracy) to the same degree as Christian theology has. We may consider this as a kind of 'critique of Islam' in the sense that 
Habermas urges Islamic scholars and theologians to make the religion more compatible with these norms: "[ $\mathrm{t}]$ hey are expected to appropriate the secular legitimation of constitutional principles under the premises of their own faith" (2008a, 27). According to Jansen, however, Habermas is not just proposing a discursive critique of religion, he also "generalizes about Muslims in terms of how their assumed orthodoxy would determine their identities in a liberal democracy" (2011, 990), drawing on "earlier European imaginaries" about the fanaticism of Islam and Muslims:

Voltaire's Mahmot ou le fanatisme is famous in this regard, but it is also important to know that Kant, although he does treat Islam systematically, says some occasional things about it in his anthropology, actually in the part on mental diseases 'Fanaticism [Schwärmerei], 'the most dangerous human deceptive screen [Blendwerk], leads to extremities such as 'putting Muhammad on the throne' (Ibid., 990).

This is misleading because Habermas nowhere portrays Islam as inherently fanatic, or essentially different from other religions. Habermas regards Islam as a world religion from which secular philosophy has learned a lot: "Philosophy has repeatedly learned through its encounters with religious traditions - and also, of course, with Muslim traditions" (2008, 142). Furthermore, Habermas explicitly states - rightly or wrongly - that Islam is on the same path as European Catholicism and Protestantism. Thus, in contrast to islamophobic ideas about Islam as a threat or a fundamental 'other' (Mavieli 2012), Habermas emphasizes the similarities between Islam and Christianity, suggesting however that Christianity has made greater progress when it comes to integrating liberal democratic norms into its doctrinal core. Jansen therefore goes too far when claiming that Habermas is "spreading prejudice about Islam and Muslims" $(2011,992)$. There is no emphasis in Habermas on Muslims as problems or threats; on the contrary, the general tendency is characterize to Muslims as a resource, and to stress the need to include Muslisms as Muslims in existing political cultures: "Muslim immigrants cannot be integrated into Western society in defiance of their religion but only with it" $(2008 \mathrm{a}, 25)$. $^{10}$

However, I am still somewhat uncomfortable with Habermas' use of the term 'Islam' in the German version of the quotation above, and also with his generalized comparison of 'Islam' and 'Christianity'. Habermas should have made it clearer that neither Islam nor Christianity has an essence or stable unity, but consists of a multiplicity of traditions,

\footnotetext{
${ }^{10}$ I elaborate my refusal of the argument that Habermas' theory is Eurocentric and hostile to Islam in Jakobsen 2017, part V.
} 
scriptural interpretations, customs, groups, sects, and so forth, that is, he should have refrained from speaking in evaluative terms about 'Islam' and other religions as such. Recognizing internal diversity in cultural-religious traditions is an epistemic virtue because it makes the discussion more focused: which version of Islam are we talking about? It is also a moral virtue because it avoids the stigmatization involved in saying that all versions of Islam - and therefore potentially all Muslims - have a 'learning process' before them.

To sum up, moderate inclusivism agrees with Habermas that the process of separating church and state is much more advanced in Western democracies than in societies in which religious worldviews, institutions, practices etc. plays a dominant structuring role, or did until recently. At the same time, moderate inclusivism is more careful not to compare religions as if they were unified and internally consistent wholes. Also, moderate inclusivism assumes that citizens who support the basic principles of a liberal democratic regime are also able and willing to obey the CTP, that is, to offer to fellow citizens a non-sectarian justification in political disputes, if asked to do so. By this, moderate inclusivism has another advantage over Habermas' own formulation of the ethics of citizenship, namely that it distributes the normative expectations of democratic citizenship equally, rather than premising these expectations on a grand theory about different religions and the ethical competencies associated with their members.

\section{Literature}

Audard, Catherine. 2011. "Rawls and Habermas on the Place of Religion in the Political Domain". In Finlayson, James Gordon \& Freyenhagen, Fabien (eds.): Rawls and Habermas: Disputing the Political. New york, London: Routledge.

Audi, Robert. 1997. "Wolterstorff on Religion, Politics, and the Liberal State", in Audi, Robert and Wolterstorff, Nicholas: Religion in the Public Square: The Place of Religious Convictions in Political Debate. London: Rowman and Littefield.

Boettcher, James W. 2009. "Habermas, Religion and the Ethics of Citizenship". In Philosophy and Social Criticism, vol. 35, nos. 1-2.

Calhoun, Craig. 2011. "Secularism, Citizenship, and the Public Sphere", in Calhoun, Craig; Vanantwerpen, Jonathan \& Juergensmeyer, Mark (eds.): Rethinking Secularism. Oxford: Oxford University Press.

Chambers, Simone. 2007. "How Religion Speaks to the Agnostic: Habermas on the Persistent Value of Religion". Constellations 14 (2), pp. 210 - 223.

Chambers, Simone. 2010. "Secularism Minus Exclusion: Developing a Religious Friendly Idea of Public Reason". The Good Society, Vol. 19, No. 2.

https://muse.jhu.edu/article/409109/pdf 
Cooke, Maeve. 2007. “A Secular State for a Postsecular Society? Postmetaphysical Political Theory and the Place of Religion". In Constellations 14 (2), pp. $224-238$.

Eberle, Christopher. 2002. Religious Conviction in Liberal Politics. New York, NY: Cambridge University Press.

Forst, Rainer. 2011. The Right to Justification. Colombia University Press.

Habermas, Jürgen. 1998. Between Facts and Norms. Contributions to a Discourse Theory of Law and Democracy. Massachusetts: The MIT Press.

Habermas, Jürgen. 2003a. "Citizenship and national Identity”, in Steenbergen, Bart Van (ed.) The Condition of Citizenship. London, Thousand Oakes and New Delhi: Sage Publications.

Habermas, Jürgen. 2003b. "Faith and Knowledge". In The Future of Human Nature, Cambridge: Polity Press.

Habermas, Jürgen. 2006. "Political Communication in Media Society: Does Democracy Still Enjoy an Epistemic Dimension? The Impact of Normative Theory on Empirical Research", in Communication Theory, vol. 16, pp. 411-426.

Habermas, Jürgen. 2008. Between Naturalism and Religion. Cambridge: Polity Press.

Habermas Jürgen. 2008a. "Notes on Post-secular Society", in New Perspectives Quarterly, Vol. 25, Issue 4, pp. 17-39.

Habermas, Jürgen. 2008b. "Die Dialektik der Säkularisierung”, in Blätter für deutsche und internationale Politik, no. 4, pp. 33-46.

Habermas, Jürgen. 2012. Nachmetaphysiches Denken. Berlin: Suhrkamp.

Habermas, Jürgen. 2013. "Reply to my Critics", in Calhoun, Craig; Mendieta, Eduardo \& VanAntwerpen, Jonathan (eds.): Habermas and Religion. Cambridge: Polity Press.

Habermas, Jürgen \& Taylor, Charles. 2011. "Dialogue". In Mendieta, Eduardo \& Vanantwerpen, Jonathen (eds.): The Power of Religion in the Public Sphere. New York: Colombia University Press.

Holst, Cathrine \& Molander, Anders. 2015. "Jürgen Habermas on Public Reason and Religion: Do Religious Citizens Suffer an Asymmetrical Cognitive Burden, and Should They be Compensated?". In Critical Review of International Social and Political Philosophy, 18: 5, pp. $547-563$.

Jakobsen, Jonas. 2017. The Claims of Freedom: Habermas' Deliberative Multiculturalism and the Right to Free Speech. Doctoral Thesis, UiT - The Arctic University of Norway. Available at: https://munin.uit.no/handle/10037/10962.

Jakobsen, Jonas, \& Fjørtoft, Kjersti. 2018. "In Defense of Moderate Inclusivism: Revisiting Rawls and Habermas on Religion in the Public Sphere". In Etikk I Praksis - Nordic Journal of Applied Ethics, 12(2), 143-157. https://doi.org/10.5324/eip.v12i2.2267.

Jansen, Yolande. 2011. "Postsecularism, piety and fanaticism: Reflections on Jürgen Habermas' and Saba Mahmood's critiques of secularism”, in Philosophy and Social Criticism 37 (9), pp. 977-998. 
Jensen, Mark. 2005. “The Integralist Objection to Political Liberalism”. In Social Theory and Practice, Vol. 31, No. 2.

Laborde, Cécile. 2017. Liberalism's Religion. Cambridge, Massachusetts: Harvard University Press.

Lafont, Cristina. 2013. "Religion in the Public Sphere. What are the Deliberative Requirements of Democratic Citizenship?", in Calhoun, Craig; Mendieta, Eduardo; VanAntwerpen, Jonathan (eds.): Habermas and Religion. Cambridge: Polity Press.

Mavieli, Luca. 2012. Europe's Encounter with Islam: The Secular and the Postsecular. London \& New York: Routledge.

March, Andrew. 2013. "Rethinking Religious Reasons in Public Justification". In American Political Science Review, Vol. 107, No. 3 (August 2013) pp. 523-539.

McCarthy, Thomas. 2013. "The Burdens of Modernized Faith and Postmetaphysical reason Reason in Habermas' 'Unfinished Project of Modernity', in

Calhoun, Craig; Mendieta, Eduardo; VanAntwerpen, Jonathan (eds.): Habermas and Religion. Cambridge: Polity Press.

Neal, Patrick. 2014. "Habermas, Religion, and Citizenship". In Politics and Religion 7 (02), pp. $318-338$.

Nussbaum, Martha C. 2012. The New Religious Intolerance: Overcoming the Politics of Fear in an Anxious Age. Cambridge: The Belknap Press.

Al-Qaradawi, Yusuf. 1994. The Lawful and the Prohibited in Islam. Indiana: American trust Publications.

Rawls, John. 2005. Political Liberalism (expanded edition). New York: Colombia University Press.

Rostbøll, Christian F. 2008. Deliberative Freedom. Deliberative Democracy as Critical Theory. New York: State University of New York Press.

Taylor, Charles. 2011. "Why We Need a Radical Redefinition of Secularism". In Mendieta, Eduardo \& Vanantwerpen, Jonathen (eds.): The Power of Religion in the Public Sphere. New York: Colombia University Press.

Thomassen, Lasse. 2006. "The Inclusion of the Other? Habermas and the Paradox of Tolerance”. In Political Theory, 34 (4), pp. 439-462.

Waldron, Jeremy. 2012. "Two-Way Translation: The Ethics of Engaging with Religious Contributions in Public Deliberation”. In Mercer Law Review. 63(3), pp. 845-868.

Wolterstorff, Nicholas. 1997. "Why We Should Reject What Liberalism Tells Us About Speaking and Acting in Public for Religious Reasons". In Religion and Contemporary 
Liberalism, edited by Paul J. Weithman, pp. $162-81$. Notre Dame: University of Notre Dame Press.

Wolterstorff, Nicholas. 1997a. "The Role of Religion in Decision and Discussion of Political Issues". In Audi, Robert \& Wolterstorff, Nicholas: Religion in the Public Square: The Place of Religious Convictions in Political Debate, New York: Rowman \& Littlefield.

Yates, Melissa. 2007. "Rawls and Habermas on Religion in the Public Sphere", in Philosophy and Social Criticism, 33 (7), pp. 880-891. 